\title{
PERFORMANCE AND TEXT (BASED UPON THE MATERIALS FROM ONLINE ARCHIVE 'ODESSA ART IN 1980-S')
}

\author{
Gladun Daryna \\ PhD student \\ ORCID ID 0000-0002-9114-7168 \\ Taras Shevchenko Institute of Literature \\ National Academy of Science of Ukraine \\ 4, Mykhailo Hrushevskoho St, Kyiv, 02000, Ukraine \\ daryna.gladun@gmail.com
}

The article studies the role of the text in performances conducted during $1980 \mathrm{~s}$ in Odessa by the participants of so-called 'Odessa school' Serhiy Anufriyev, Leonid Voytsekhov, Yuriy Leyderman, Svitlana Martynchyk, Volodymyr Naumets, Alexander Petrelli, Oleh Petrenko, Liydmyla Skrypkina, Ihor Styopin, Ihor Tshatskin (solo or as participants of art groups 'IU', 'Martynchyky', 'Pertsi'.

Following research discovers, systematizes, and analyzes materials of online archive 'Odessa Art of 1980s' created in 2000 by Odessa Centre of Contemporary Art in collaboration with Institute of Contemporary Art.

The article, therefore, overviews over twenty individual and collective pieces of Performance Art, in particular: 'Cross-Zero' (1982), 'Russian Idyll ' (1982), 'Pacifist Demonstration' (1983), 'Leaning Against Pillar' (1983), "[Among Other Things]» (1983), 'I Admire Friends' (1983), 'David's Shield' (1983), «Basin» (dedicated to 'Muhomory') (1984), 'This Secret Word' (1984), 'Flag Killing Methods' (1985), 'There I Were a Man' (1985), 'To Hit a Wall and a Black Wife' (1987), 'Like a Shot' (1987), 'The Most Precious' (1987), 'Exploration of Art Deposits' (1987), 'Vasia Was Here' (1987) etc. as well as performance-exhibition 'Relatives' (1983). The attribution and description of all studied pieces of Performance Art is based exclusively on the data gained from the online archive (even though some of the data are controversial). The performances mentioned in the archive are catalogized. The main challenges of the archive-based research in performance studies are underlined.

Keywords: 'Odessa school', text, archive, performance art, performance, happening.

\section{ПЕРФОРМАНС І ТЕКСТ (НА ОСНОВІ МАТЕРІАЛІВ 3 ОНЛАЙН-АРХІВУ «МИСТЕЦТВО ОДЕСИ 1980-Х»)}

\section{Гладун Дарина}

Аспірантка

ORCID ID 0000-0002-9114-7168

Інститут літератури ім. Т. Г. Шевченка

Національної академії наук України вул. Михайла Грушевського, 4, Київ, 02000, Україна daryna.gladun@gmail.com

Стаття присвячена вивченню авторського тексту у перформансах, щзо відбулися в м. Одеса у 1980-х роках. У иентрі дослідження перебувають геппенінги й перформанси представників «одеської школи»: С. Ануфрієва, Л. Войцехова, Ю. Лейдермана, С. Мартинчик, В. Наумия, О. Петреллі, О. Петренка, Л. Скрипкіної, I. Стьопіна, I. Чаџкіна проведені індивідуально, а також у складі мистецьких груп «IЮ», «Мартинчики», «Периіџ».

(C) Gladun D., 2020 
Дослідження зосереджене на вивченні, систематизації й аналізі матеріалів онлайн-архіву «Мистецтво Одеси 80-х», створеного Центром сучасного мистеитва (м. Одеса) й Інститутом сучасного мистеитвва у 2000 p.

У рамках статті розглянуто понад двадиять авторських (індивідуальних $i$ колективних) творів мистецтвва перформанс: "Російська ідилія» (1982), "ХрестикНулик» (1982), “[Між іншим]» (1983), «Пацифістська демонстрація» (1983), «Притуливиись до стовпа» (1983), «Щит Давида» (1983), «Я захоплююся друзями» (1983), «Таз» (присвята «Мухоморам») (1984), «Це таємне слово» (1984), «Способи вбивства прапором» (1985), «Я був мужиком там» (1985), «Бити по стіні і по чорній дружині» (1987), «Найбільш сокровенне» (1987), «Розвідка художніх копалин» (1987), «Тут був Вася» (1987), «У два рахунки» (1987) тощуо, а також виставкуперформанс «Рідня» (1983). Атрибутування ц̌ опис усіх досліджених творів мистецтва перформанс здійснене винятково на основі (подекуди суперечливих) даних, які вдалося відшукати серед матеріалів онлайн-архіву (переважно фотодокументацій, інтерв 'ю, листів). Проведено каталогізацію дійств. Окреслено проблемні моменти дослідження текстового складника перформансів на основі архівних матеріалів.

Ключові слова: «одеська икола», текст, архів, мистеитво перформанс, перформанс, геппенінт.

На основі матеріалів онлайн-архіву «Мистецтво Одеси 80-х», створеного в 2000ому році Центром сучасного мистецтва м. Одеса й Інститутом сучасного мистецтва, у статті буде розглянуто способи використання текстів у перформансах представників неофіційного мистецтва 1980-х. Упорядкування зазначеного вище архіву супроводжувала серія інтерв'ю В. Безпрозванного й О. Годиної, які стали основою для подальших досліджень феномену «одеської школи» сучасними культурологами й мистецтвознавцями Г. Вишеславським, Т. Кочубінською, О. Тряновою тощо. Попри значний інтерес мистецьких інституцій України (НХMУ, PinchukArtCentre, MCMO) до творчості представників «одеської школи», онлайн-архів «Мистецтво Одеси 80-х» дотепер залишається одним із ключових джерел інформації про творчість одеських митців означеного періоду. Втім, критики й науковці переважно не досліджують архів систематично, тому наразі у статтях зустрічаємо різне датування виставкиперформансу «Рідня», паралельно функціонують різні назви перформансів Ю. Лейдермана та І. Чацкіна тощо.

Вивченню перформансів із текстовим складником присвячено роботи К. Грібнер, М. Карлсона, Г. Франссена та ін. Дослідники акцентують увагу на необхідності різновекторного аналізу текстів дійств, а також зв'язку тексту і дії. Текстовий вимір перформансів також розглянуто в статтях українських науковиць I. Нечиталюк («Український літературний перформанс», 2014) та Ю. Починок («Перформанс як медіа-текст», 2014), втім, у фокусі цих досліджень опинилися, головно, візуальні складники перформансів письменників Ю. Андруховича, Н. Гончара, С. Жадана, В. Махна, Т. Прохаська. Літературні перформанси візуальних митців дослідниці залишили поза дужками. Натомість, стаття М. Пашкевич «Перформансна комунікація: витоки та трансформації» (2017), в якій, зокрема, йдеться і про діяльність молодих одеських митців 1980-х, зосереджена на комунікативному аспекті дійств, але не аналізує безпосередньо тексти. Неофіційному мистецтву Одеси 1980-х присвячено розділи монографій літературознавця Я. Поліщука («Фронтирна ідентичність: Одеса ХX століття», 2019) та мистецтвознавиці А. Ложкіної («Перманентна революція», 2019). На жаль, ці дослідження не дають вичерпної характеристики ролі тексту в перформансах, що відбулися в Одесі у 1980-х роках, а зосереджені, головно, на аналізі візуальних складових дійств.

Мета цієї статті - встановити наявність текстових складників у перформансах одеських митців, що відбулися в м. Одеса протягом 1980-1989 років, на основі 
матеріалів онлайн-архіву «Мистецтво Одеси 80-х», а також окреслити специфіку функціонування тексту в означених перформансах.

Основними завданнями статті є:

1) систематично вивчити матеріали онлайн-архіву «Мистецтво Одеси 80-х»;

2) каталогізувати перформанси, інформація про які наявна в архіві;

3) встановити наявність (або відсутність) текстового складника в каталогізованих перформансах;

4) проаналізувати функції текстового складника в каталогізованих перформансах.

Завдання будуть виконані шляхом використання аналітичного методу. Аналітичний метод буде застосовано для каталогізації перформансів й виокремлення специфічної ролі текстової складової у кожному з них.

Наукова новизна цієї статті полягає у систематичному дослідженні матеріалів онлайн-архіву «Мистецтво Одеси 80-х».

Об’єкт дослідження - матеріали онлайн-архіву «Мистецтво Одеси 80-х».

Предмет дослідження - фотодокументації дійств, ескізи до перформансу Ю. Лейдермана, комп'ютеропис листів Л. Войцехова, Ю. Лейдермана, І. Чацкіна, інтерв'ю М. Алексеєва, С. Ануфрієва, Л. Войцехова, В. Захарова, К. Звездочетова, I. Камінника, Ю. Лейдермана, С. Мартинчик, В. Мироненка, А. Монастирського, Д. Нужина, М. Паніткова, О. Петреллі, О. Петренка, С. Подлипського, Л. Резун, Л. Скрипкіної, І. Стьопіна, П. Фоменка, І. Чацкіна.

Усний і письмовий авторські текси як складові творів мистецтва перформанс можуть бути створеними заздалегідь (до початку дійства) або імпровізованими під час дійства і мати різний ступінь імпровізованості (у межах заданої теми або проблематики, бути неконтрольованим потоком думки тощо). Спогади про перформанс, зафіксовані в інтерв'ю, листах, щоденникових записах і будь-якій іншій формі не можна вважати текстовим складником перформансу, втім, вони можуть підтвердити або спростувати наявність авторського тексту в перформансі, а також допомогти встановити специфіку функціонування авторського тексту в дійстві.

Як зазначено вище, дослідження спирається на матеріали онлайн-архіву «Мистецтво Одеси 80-х», впорядкованого за іменами митців, у якому наявні розділи:

1) біографія;

2) інтерв'ю;

3) фотографії;

4) роботи;

5) листи;

6) тексти.

У розділі «Біографія» подано недеталізовану біографію митців у формі хронологічної таблиці. Оскільки метою впорядкування онлайн-архіву було формування хронології виставкової діяльності митців, перформанси не потрапили до хронологічної таблиці на сторінках із біографіями. Розділ «Інтерв'ю» містить тексти інтерв'ю, які провели В. Безпрозванний та О. Година під час укладання архіву. Розділ «Фотографії» містить світлини, а «Роботи» - цифрові копії живопису, графіки, об'єктів тощо, а також знімки скульптур та інсталяцій, датовані періодом 1980-1990х. Розділ «Листи» містить комп'ютерописи листів, датованих першою половиною 1980-х. Розділ «Тексти» містить п’ять недатованих поетичних творів дуету «Мартинчики».

В архіві наявні шістнадцять тематичних рубрик (за іменами художників і творчих груп), присвячених С. Ануфрієву, Л. Войцехову, І. Зільберштейну, Ю. Лейдерману, O. Музиченку, Д. Нужину, О. Петреллі, Г. Подвойському, С. Подлипському, Л. Резун, В. Сальникову, І. Чацкіну, об’єднанням «Мартинчики» (учасники: С. Мартинчик, I. Стьопін), «Перці» (учасники: О. Петренко, Л. Скрипкіна), «Фомський» (учасники: I. Камінник, П. Фоменко). Шістнадцята рубрика «Москвичі» 
складається $з$ інтерв’ю М. Алексеєва, В. Захарова, К. Звездочетова, В. Мироненка, А. Монастирського (за участі Ю. Лейдермана), М. Паніткова.

Проаналізувавши дані архіву, наводимо перелік мистецьких акцій, що відбулися в м. Одеса у період з 1981 до 1989 р., зафіксовані на світлинах, згадані в листах й інтерв'ю' :

1) Перформанс «Хрестик-Нулик», 1982 р. Учасники: С. Ануфрієв, В. Наумець. Місце проведення: м. Одеса.

В архіві «Мистецтво Одеси 80-х» наявна одна світлина 3 документацією дійства [див. Фото 1] ${ }^{2}$. Будь-які інші згадки відсутні. На жаль, на основі даних архіву, не вдалося встановити або спростувати наявність текстової складової дійства.

2) Перформанс «Без назви», 7.09.1982 р. Автори й учасники: Ю. Лейдерман, I. Чацкін. Місце проведення: публічний простір м. Одеса.

Напередодні дійства Ю. Лейдерман й І. Чацкін роздали друзям запрошеннякартки $з$ текстом: «7.IX.82 в м. Одеса о 10 год 03 хв, за Московським часом, відбудеться периий в історії людства пілотований політ думки» [див. Іл. 1] Подібний текст знаходимо також у спогадах Л. Войцехова: «I завтра о другій дня на Соборній площчі відбудеться перший в історії людства пілотований політ вільної думки». Детального опису дійства в архіві не знайдено. Вкрай абстрактно описує його Л. Войцехов, стверджуючи, що під час перформансу І. Чацкін «трохи літав» [1]. Відтак, можна констатувати наявність текстової складової в перформансі «Без назви» (07.09.1982) принаймні на підготовчому етапі, втім, встановити, чи виконувала вона іншу роль, окрім інформативної, не вдалося.

3) Перформанс «Російська ідилія» ${ }^{4}, 1982$ р. Автори й учасники: об'єднання «ІЮ» (Ю. Лейдерман, І. Чацкін). Місце проведення: публічний простір м. Одеса. Тривалість дійства: 3 години.

Для перформансу «Російська ідилія», що відбувався «на схилах і на бульварі» м. Одеса, Ю. Лейдерман створив графічні роботи, на яких зображені викривлені обличчя людей. Аркуші з роботами «були прибиті цвяшками до дерев» [2]. Цікаво, що автори перформансу по-різному описують перебіг дійства. Так, Ю. Лейдерман пригадує, що I. Чацкін пародіював карикатурні обличчя власною мімікою [3]. Світлина $з$ архіву Ю. Лейдермана підтверджує слова художника [див. Фото 2]. Втім, I. Чацкін стверджує, що ці карикатурні обличчя пародіював Ю. Лейдерман. За словами I. Чацкіна, у другій частині дійства обидва перформери танцювали навприсядки [2]. Ю. Лейдерман це підтверджує, втім, говорить, що дійство складався не 3 двох, а $з$ трьох частин: першу (описану вище) придумав I. Чацкін, друга - танці навприсядки - була вигадана спільно, а третю придумав Ю. Лейдерман [3] (перебіг третьої частини Ю. Лейдерман не коментує). Інформації щодо наявності текстового складника в перформансі «Російська ідилія» в онлайн-архіві «Мистецтво Одеси 80-х» не знайдено.

4) «Пацифістська демонстрація», 13.03 .1983 р. Автори: Ю. Лейдерман, С. Мартинчик, О. Петренко, Л. Скрипкіна, I. Чацкін ${ }^{5}$ Учасниці: С. Мартинчик, Л. Скрипкіна. Місце проведення: публічний простір м. Одеса.

Як пригадує мисткиня Л. Скрипкіна, менше ніж за тиждень до початку демонстрації, автори дійства, домовившись між собою про його проведення,

\footnotetext{
${ }^{1}$ Матеріали онлайн-архіву «Мистецтво Одеси 80-х» написані російською мовою. Усі цитати, наведені в статті, подані в авторському перекладі.

${ }^{2}$ Фотографії розміщені наприкінці статті.

${ }^{3}$ Ілюстрації розміщені наприкінці статті.

${ }^{4}$ I. Чацкін називає цей перформанс «Росіяни ми росіяни, вузькі ми вузькі» [2].

5 А також, за словами О. Петренка, «Микола і його дівчина», особи яких встановити не вдалося. Втім, у тому ж інтерв’ю Л. Скрипкіна говорить, що підписалися під листами лише п’ятеро [4].
} 
написали листи «в ООН, кудись у Москву», О. Петренко додає, що один лист надіслали у «Вечірню Одесу». У текстах листів ${ }^{1}$ група митців висловила намір пройти 3 пацифістською демонстрацією «проти війни». За словами О. Петренка, наступного дня після надсилання листів, митців викликали на допит [4]. Це підтверджують Л. Скрипкіна [4] й І. Чацкін [2]. Тому в демонстрації взяли участь не всі автори дійства, а лише С. Мартинчик і Л. Скрипкіна, які пройшли «від пам'ятника Пушкіну до Куликового поля» удвох, оточені міліцейським кордоном [4]. I. Чацкін називає цю акцію проявом соціальної незатребуваності митців і підкреслює, що в Одесі того періоду твори молодих художників «не мали глядачів». Тому «Пацифістська демонстрація» була «нездійсненною мрією про глядача» [2].

У даному разі листи декларували нонконформістські настрої цієї групи молодих художників, які в письмовій формі висловили власний протест проти воєнних дій (як свідчить Л. Скрипкіна, під час формування задуму дійства і написання листів митці обговорювали війну в Афганістані [4]).

5) Перформанс «Без назви», [1983]. Автори й учасники: Ю. Лейдерман, I. Чацкін.

Про перформанс в онлайн-архіві «Мистецтво Одеси 80-х» наявні точкова згадка в інтрев'ю А. Монастирського [5] й одна світлина з фотодокументацією перформансу з приватного архіву Л. Резун (копія цього знімка стала частиною альбому С. Ануфрієва «Мадонни» [див. Іл. 2]). На основі цих даних встановити або спростувати наявність тексту в дійстві не вдалося.

6) Перформанс «Притулившись до стовпа», 1983 р. Учасник: Ю. Лейдерман. Перформанс у публічному просторі м. Одеса, про який серед архівних матеріалів свідчить лише чотири світлини [див. Фото 3]. Встановлення або спростування наявності текстового складника в дійстві потребує більшої кількості даних.

7) Перформанс «[Між іншим]», 1983 р. Учасник: Л. Войцехов. Місце проведення: квартира Л. Войцехова (вул. Асташкіна, м. Одеса).

В архіві не знайдено жодних згадок про дійство, окрім двох світлин з приватного архіву Л. Войцехова, на яких задокументовано перформанс [див. Фото 4]. Як бачимо на світлині, під час дійства Л. Войцехов сидів на пеньку в колі карток із написом «МІЖ ІНШИМ». Відтак, текст у дійстві виконував функцію фізичного бар'єру між перформером і глядачами та мав важливе значення для інтерпретації дійства.

Перформер обирає центр простору й займає його, проте усвідомлює, що периметр який він окреслив перебуває на периферії (художник робить перформанс не у приміщенні музею, а у власній квартирі провінційної Одеси), на маргінесах мистецького процесу СРСР, нехай навіть він - ключова постать одеського мистецтва 1980-х, та його роль у радянському й світовому контекстах не головна, $\mathrm{i}$ навіть не другорядна, а ніби «між іншим».

8) Перформанс «Я захоплююся друзями», 1983. Автор: Ю. Лейдерман.

В онлайн-архіві зберігаються лише копії аркушів 3 колекції А. Монастирського й архіву «Перців», які були використані під час перформансу [див. Іл. 3]. Відтак, можемо встановити наявність текстового складника. На жаль, цих матеріалів не достатньо для реконструкції перебігу перформансу й окреслення ролі тексту в дійстві.

9)Перформанс «Щит Давида», 1983 р. Автори: Ю. Лейдерман, І. Чацкін. Учасник: Ю. Лейдерман. Місце проведення: м. Одеса.

Інформація про дійство в архіві обмежується точковою згадкою в інтерв'ю А. Монастирського [5] і фотодокументацією 3 приватного архіву Ю. Лейдермана [див. Фото 5]. Дані про перебіг подій під час перформансу відсутні, а подальший його аналіз потребує додаткової інформації.

${ }^{1}$ В архіві ці листи відсутні. 
10) Виставка-перформанс «Рідня», літо $1983 \mathrm{p}^{1}[1 ; 4]$. Автори й учасники: С. Ануфрієв, Л. Войцехов, Ю. Лейдерман. Місце проведення: квартира М. Жаркової (вул. Сонячна, м. Одеса) [6].

Важливою для «Рідні» став процес підготовки до відкриття виставки, в рамках якого всіх потенційних відвідувачів (досить стале коло людей, які збирались у салонах М. Жаркової) поінформували, що на новій виставці будуть «неймовірні роботи в нових техніках». За словами Л. Войцехова, ідея виставки полягала у невідповідності декларованої інтенції («виставка неймовірних робіт»), наявним в експозиційному просторі роботам, «до яких були приклеєні фотографії батьків». Кожного відвідувача виставки на порозі зустрічав екскурсовод (Ю. Лейдерман або С. Ануфрієв), який мав максимально детально розповідати про всі родинні зв'язки людей на світлинах (ім'я, професію, ступінь спорідненості, місце проживання тощо) [1].

Відтак, ключову роль у виставці-перформансі відіграв усний імпровізований текст. Втім, імпровізація відбувалась у чітких рамках, обмежених постатями героїв світлин і їхніми біографіями. Інформація щодо наявності підготовчих текстів (усних або письмових) в архіві відсутня.

11)Перформанс «Це таємне слово», 1984 р. Автори: Ю. Лейдерман, І. Чацкін. Учасники: Л. Войцехов, Ю. Лейдерман, О. Петренко, Л. Скрипкіна, І. Чацкін. Місце дії: квартира Л. Войцехова (вул. Асташкіна, м. Одеса).

Матеріали про перформанс обмежуються світлинами 3 приватних архівів Л. Войцехова та Ю. Лейдермана [див. Фото 6], а також копіями аркушів-атрибутів із текстом [7]. Тож можна констатувати наявність текстової складової в перформансі, втім, для визначення ролі тексту у дійстві необхідні додаткові дані.

12)Перформанс «Таз» ${ }^{2}$ (присвята «Мухоморам» ${ }^{3}$ ), жовтень 1984 р. Автор: О. Петреллі. Місце проведення: публічний простір м. Одеса (вулиці, бари); дім Г. Подвойського.

За словами автора, ідея дійства виникла під час прослуховування магнітоальбому «Золотий диск» об’єднання «Мухомори». Протягом дійства учасники спілкувалися й відвідували різні бари м. Одеса. Кінцевим пунктом їхнього маршруту стала дача Г. Подвойського [8].

С. Ануфрієв говорить, що це - перше дійство, автором якого став О. Петреллі [6]. Точкова згадка про перформанс є в інтерв'ю «Перців» [4]. В архіві «Мистецтво Одеси 80-х» збережено шість світлин, на яких задокументовано перформанс [див. Фото 7].

На основі наявного матеріалу робимо висновок, що імпровізований усний текст грав важливу роль у дійстві, оскільки автор давав учасникам інструкції щодо дій.

13) Перформанс «Способи вбивства прапором» ${ }^{4}, 1985$ р. Автори й учасники: Ю. Лейдерман, І. Чацкін. Місце проведення: квартира Л. Войцехова (вул. Асташкіна, м. Одеса).

Про перформанс $\epsilon$ дві точкові згадки в інтерв'ю Ю. Лейдермана [3] й I. Чацкіна [2]. Також збереглися 6 підготовчих рисунків [9] і 7 знімків репетиції перформансу [див. Фото 8]. Згадки про наявність текстової складової у дійстві відсутні.

14)Перформанс «Я був мужиком там», 1985 р. Автор: Ю. Лейдерман.

${ }^{1}$ Фотографії з архіву Ю. Лейдермана (в онлайн-архіві «Мистецтво Одеси 80-х»), на якій задокументовані учасники виставки «Рідня» датовані 1982 p.

${ }^{2}$ С. Ануфрієв називає дійство «Перформанс із тазом» [6].

3 «Мухомори» (1978-1982) - об'єднання московських концептуальних митців (С. Гундлах, К. Звездочетов, О. Каменський, В. Мироненко, С. Мироненко).

${ }^{4}$ I. Чацкін називає дійство «Десять способів убивства прапором» [4]. 
В архіві збережено лише два знімки дійства (на яких письмовий текст не фігурує). Відтак, встановити або спростувати наявність текстового складника в перформансі на основі матеріалів онлайн-архіву «Мистецтво Одеси 80-х» не вдалося.

15)Перформанс «Бити по стіні і по чорній дружині», 1987 р.

Автор: Ю. Лейдерман. Учасники: Ю. Лейдерман, Л. Скрипкіна.

Про перформанс є дві точкові згадки в інтерв 'ю Ю. Лейдермана [3] і «Перців» [4]. В архіві збережено 6 світлин, на яких задокументовано перформанс (письмовий текст на світлинах відсутній). Встановлення або спростування наявності тексту в перформансі потребує додаткових даних.

16) Перформанс «В два рахунки», 1987 р. Спільний перформанс одеських (Л. Войцехов [10]) і московських (учасники об’єднання «Чемпіони світу» [11]) художників ${ }^{1}$. Місце проведення: сквер Пале-Рояль, м. Одеса.

В архіві збережено 18 світлин, на основі яких можна частково реконструювати перебіг дійства. Зокрема, можемо відзначити, що фарбою на асфальті було зроблено напис «В два рахунки. Москва-Одеса '87»; також відбулося «миття асфальту»у сквері «Пале Рояль» [див. Фото 9] (це підтверджує в інтерв’ю К. Звездочетов [11]).

17) Дійство «Найбільш сокровенне», 1987 р. Авторка й учасниця: С. Мартинчик. Місце проведення: сквер Пале-Рояль, м. Одеса.

Про «Найбільш сокровенне» в інтерв’ю згадує I. Камінник [12]. Художник стверджує, що С. Мартинчик ходила з сумкою, на якій було написано: «Найбільш сокровенне». За можливість подивитись у сумку мисткиня брала певну платню (двадцять копійок). За словами митця, у сумці були засоби жіночої гігієни («ватні тампони»), вимащені червоною фарбою [12].

Про дійство згадує в інтерв'ю й сама авторка, яка уточнює, що сумка була наповнена «імітацією жіночих гігієнічних прокладок», виготовлених із вати й туалетного паперу та розфарбованих червоною темперою. Також С. Мартинчик стверджує, що «продавала кота в мішку», відтак, йдеться про плату за товар («найбільш сокровенне»), а не послугу (огляд вмісту сумки). Мисткиня говорить, що єдиний, кому вона відмовилася продати «найбільш сокровенне» - «маленький хлопчик, який випросив 20 копійок у батьків» [10]. Відзначу, що сквер Пале-Рояль на той час був місцем неофіційної торгівлі, де художники часто продавали сувенірну продукцію власного виробництва. Тож це дійство також можна розглядати як успішний приклад впровадження маркетингової стратегії для продажу продукту, на який на ринку сувенірної продукції не було попиту, за ціною значно вищою від собівартості.

Текст «найбільш сокровенне», нанесений на велику чорну сумку перформерки, у цьому дійстві відіграв ключову роль, перетворивши продаж «кота в мішку» на іронічний феміністичний жест. С. Мартинчик продавала глядачам дійства не саму річ (мисткиня зазначає, що більшість об'єктів покупці одразу викидали) [10], а привід для роздумів на тему менструації, табуйовану в публічному просторі СРСР.

18)Перформанс «Розвідка художніх копалин» ${ }^{2}$. Спільний перформанс групи одеських і московських художників ${ }^{3}$. Місце проведення: сквер Пале-Рояль, м. Одеса.

С. Подлипський пригадує, що необхідним геодезичним приладдям дійство забезпечив митець О. Петреллі, який також давав поради щодо специфіки сленгу геодезистів [13]

Ще один елемент, пов'язаний із перформансом - об'єкт Ю. Лейдермана, на якому записано діалог: «Мама: «Ти збираєшся нарешті вдягнути купальник, Машенько?!»

${ }^{1}$ Повний перелік учасників на основі даних, наявних в онлайн-архіві «Мистецтво Одеси 80-х», встановити не вдалося.

${ }^{2}$ Г. Подлипський називає дійство «Геодезичний вимір» [13].

3 Повний перелік учасників на основі даних, наявних в онлайн-архіві «Мистецтво Одеси 80-х», встановити не вдалося. 
Машенька: «Мамо, у тебе неймовірна здатність ставити дурнуваті питання!» [див. Фото 10]. На жаль, спосіб використання об’єкту під час перформансу в архіві не вказано.

Окрім цієї світлини, наявні ще 24 (з приватного архіву Л. Войцехова), на яких задокументовано перебіг дійства. Не зважаючи на те, що для аналізу ролі тексту в даному дійстві матеріалів замало, можна констатувати наявність (як письмового, так і усного) тексту в перформансі «Розвідка художніх копалин» [13].

19)Перформанс «Тут був Вася», 1987 р. Авторка й учасниця: С. Мартинчик. Місце проведення: сквер Пале-Рояль, м. Одеса.

В архіві зберігається одна світлина, на якій задокументовано перформанс [див. Фото 11]. На основі фотодокументації можемо констатувати наявність письмового тексту. На одязі, що висить на підрамнику, бачимо написи: «Тут був Вася». До сукні С. Мартинчик також прикріплено аркуш із текстом (прочитати текст неможливо через низьку якість зображення).

Про це дійство є точкова згадка в інтерв'ю С. Подлипського [13]. Інших згадок про перебіг дійства в архіві немає. Попри наявність письмового тексту, визначити його роль на основі архівних матеріалів не вдалося.

20) Дійство «Пильнування», 1987 р. Автори: дует «Мартинчики». Учасники: С. Мартинчик, I. Стьопін, I. Камінник та інші ${ }^{1}$. Місце проведення: квартира С. Мартинчик й І. Стьопіна, м. Одеса.

Єдине джерело інформації про дійство в архіві — інтерв'ю I. Камінника, який пригадує, що учасники сиділи в «довгих коробках 3-під ламп» і чекали на розвал Радянського Союзу [12]. Інших згадок про дійство в архіві немає. Встановити або спростувати наявність текстової складової у «Пильнуванні» на основі матеріалів онлайн-архіву не вдалося.

21) Два перформанси в рамках інспекції «Медгерменевтика», 1988 р. Учасники: І. Камінник, Ю. Лейдерман. Місце проведення: м. Одеса.

В інтерв'ю І. Камінника є згадка про місця проведення дійств: «на зрошувальних полях» і на станції «Роздільна» [12]. Відзначу, що інспекції «Медгерменевтики» зазвичай завершувалися складанням «звіту» (його наявність і факт проведення двох означених перформансів підтверджує Ю. Лейдерман [3]). На жаль, в архіві «Мистецтво Одеси 80-х» звіти інспекцій відсутні.

Також, оперуючи архівними даними, не вдалося встановити датування окремих дійств. Серед них:

1) Геппенінг «Без назви». Автори: Ю. Лейдерман, І. Чацкін.

Про дійство пише І. Чацкін у листі до Ю. Лейдермана, датованому листопадом 1981 р.: «пам'ятаєм наш геппенінг був на плитах був страшний вітер жодноі людини тільки море гігантське гігантське $і$ буро-зелена трава з сухими стеблинами $i$ Рита $^{2}$ там стояла мама сергія ${ }^{3}{ }^{4}$ [14].

Можливо, це - одне 3 дійств, про які згадує Д. Нужин, описуючи загальну тенденцію більшості тогочасних перформансів, що «не мали глядачів - лише учасників», тому «можна було почути численні розповіді про те, як хтось пішов на пляж і щось там зробив» [15]. Відсутність стороннього глядача часто означала й відсутність фотодокументації дійства. Це призвело до втрати великої кількості інформації про перформанси одеських митців 1980-х.

${ }^{1}$ Повний перелік учасників на основі даних, наявних в онлайн-архіві «Мистецтво Одеси 80-х», встановити не вдалося.

${ }^{2}$ Маргарита Жаркова.

${ }^{3}$ Сергій Ануфрієв.

${ }^{4}$ У перекладі збережено авторський синтаксис і пунктуацію.

${ }^{5}$ С. Ануфрієв стверджує, що втрачено близько 90\% інформації [2]. 
2) Перформанс «Без назви». Автор: С. Ануфрієв. Учасники: С. Ануфрієв, бабуся С. Ануфрієва ${ }^{1}$. Місце проведення: квартира М. Жаркової (вул. Сонячна, м. Одеса).

Згадку про перформанс знаходимо в інтерв'ю С. Ануфрієва, у якому митець називає дійство своїм «першим перформансом», поєднаним із боді-артом й дає його короткий опис, розповідаючи, що бабуся «поставила [йому медичні] банки» в присутності публіки салону М. Жаркової [6].

3) Геппенінг «Вони нам дадуть за це відповідь». Автори: Л. Войцехов, В. Хрущ. Л. Войцехов називає геппенінг «першим колективним невиставковим» дійством молодих одеських митців 1980-х. Геппенінг відбувся наступного дня після урагану, що за короткий проміжок часу (6-8 хвилин) повалив багато дерев у місті. Л. Войцехов і В. Хрущ спільно створили плакат (розміром $3 \times 4$ м), на якому було написано: «Вони нам дадуть за це відповідь». 3 цим плакатом містом пройшла «група людей», імена яких Л. Войцехов не називає. Художник зазначає, що в зв'язку з цим дійством його викликали на допит. За словами митця, співробітники КДБ вважали, що це - політична демонстрація, спрямована проти чинної влади, оскільки «вони не розуміли, що можна й природу притягнути до відповідальності» [1].

4) Перформанс «Устілки» (датований 1983-1984 рр.). Автор: Ю. Лейдерман.

В архіві наявна лише фотодокументація перформансу [див. Фото 12]. Об'єкти, створені протягом дійства стали основою робіт Ю. Лейдермана «Чорне лоно й черево волю мою закували» (1983), «Устілки» (1985).

5) «Власна сорочка ближча до тіла». Автор: Л. Войцехов. Дійство відбулося під егідою Творчого об'єднання художників.

Про нього згадує в інтерв’ю С. Подлипський. Митець описує дійство коротко: «Войцехов ходив 3 написом «Власна сорочка ближча до тіла» [13]. Відтак, можемо констатувати наявність у дійстві текстового складника, проте визначення його ролі потребує більшої кількості даних.

6) Геппенінг «[Чендж]». Автор: В. Федоров. Місце проведення: одна 3 кімнат комунальної квартири, у якій мешкав В. Федоров (м. Одеса).

Згадку про геппенінг знаходимо лише в інтерв'ю Д. Нужина. За словами митця, дійство «[Чендж]» полягало в обміні «всього на все». В. Федоров у кімнаті комунальної квартири, що була порожньою, поставив журнальний столик і два стільці, оголосивши цей простір місцем «грандіозного ченджу». Кімнату швидко заповнили «величезні купи речей» (ікони, фірмові фарби, апаратура тощо). Охочі здійснити обмін домовлялися за журнальним столиком. Д. Нужин стверджує, що ця кімната протягом геппенінгу ніколи не була порожньою, проте відвідуваність «ченджу» була невисокою ${ }^{2}[15]$.

Також в архіві є згадки про недатовані перформанси без назви Віті Француза ${ }^{3}$, Діка ${ }^{4}[1]$, «перформанси на Потьомкінських сходах», «перформанси Масі, перформанси Сергія 3 Машею5» [4] в м. Одеса, а також точкові згадки про перформанси, проведені художниками з Одеси в м. Москва (описи цих дійств можуть стати предметом подальших досліджень зв'язків одеських і московських художників 1980-x).

${ }^{1}$ Ймовірно, мати М. Ануфрієвої, яка мешкала з дочкою й онуком.

2 За словами Д. Нужина, дійство відвідали «п’ятдесят, плюс-мінус десять-двадцять людей» [15].

3 Справжнє ім'я - Віктор. На основі матеріалів, наявних в архіві прізвище встановити не вдалося. За словами С. Подлипського, прізвисько «Француз» Віктор отримав, оскільки володів французькою мовою [13].

${ }^{4}$ Дік Мартинчик - перший чоловік С. Мартинчик. Справжнє ім'я встановити не вдалося.

${ }^{5}$ На основі матеріалів, наявних в архіві, особи Масі, Сергія й Маші ідентифікувати не вдалося. 
Також наявні згадки про перформанс Володимира Н. Єременка у 1984-1985 рр. в м. Одеса і два дійства у м. Львів у той же період. У рамках львівських дійств відбулося «присвоєння звань» і «внесення до словника російської мови» обсценної лексики [12]. Більш детальний опис перформансів відсутній.

Цікаво, що в архівних матеріалах знаходимо згадки про майбутні (дотепер не втілені) перформанси. Так, в інтерв'ю Л. Войцехов пригадує ідеї перформансів «Веснянки» і «Книги Зайців», що з’явились у нього в 1983-1984рр. [1].

Серед фотодокументацій слід відзначити серію світлин 3 приватного архіву Ю. Лейдермана, на яких, ймовірно, зняте одне 3 «пляжних» дійств за участі Л. Скрипкіної й О. Петренка в с. Кароліно-Бугаз, Одеської обл. (1984). Втім, в описі фотографій відповідний коментар відсутній, тож це питання потребує уточнення.

Архів також містить опис симуляційного жесту «Обличчя на долонях», згаданого Л. Войцеховим в інтерв’ю В. Безпрозванному. «Обличчя на долонях» не потрапило до основного переліку перформансів, оскільки від початку відбулося як сварка двох митців (Л. Скрипкіної й О. Музиченка). За словами Л. Войцехова, осмислення цієї сварки як мистецького акту й створення документації відбулися post factum [1], тому позиціонування його як перформансу вважаємо недоцільним.

Окрім цих перформансів, в архіві «Мистецтво Одеси 80-х» $є$ також згадки про імерсивний перформанс буддійського монаха «Без назви» (1981) [14] та акцію «[Клара Будиловська]»[6], авторами яких не були представники означеного кола митців, втім, ці дійства відбулись у публічному просторі м. Одеса. У перформансі «буддійського монаха» авторський текст не було використано. Натомість, «[Клара Будиловська]» - це головно, текстова акція. За словами С. Ануфрієва, в один день у всіх без винятку районах м. Одеса на стінах з'явився напис невідомого автора: «Клара Будиловська — повія!» Пізніше «з'явилися статті [у місцевих 3МІ], що це таксист в такий спосіб помстився дружині за зраду» [6].

\section{Висновки}

1. Спираючись на ресурс онлайн-архіву, вдалося каталогізувати й атрибутувати понад двадцять дійств (серед них - одна виставка-перформанс).

2. Під час роботи 3 архівом ми вкотре зіткнулися 3 ключовими проблемами дослідження творів мистецтва перформанс: високий ступінь «зникомості» інформації про дійства, суб'єктивність і фрагментарність наявних даних.

3. На основі матеріалів онлайн-архіву «Мистецтво Одеси 80-х» вдалося встановити наявність текстового складника у дійствах «Без назви» (1982), «В два рахунки», «Власна сорочка ближча до тіла», «Вони нам дадуть за це відповідь», «[Між іншим]», «Найбільш сокровенне», «Пацифістська демонстрація», «Розвідка художніх копалин», «Таз» (присвята «Мухоморам»), «Тут був Вася», «Це таємне слово», «[Чендж]», «Я захоплююся друзями», а також у виставці-перформансі «Рідня» і двох перформансах в рамках інспекції «Медгерменевтика».

4. Вдалося у загальних рисах окреслити значення текстового складника у виставці-перформансі «Рідня» й у дійствах «[Між іншим]», «Найбільш сокровенне», «Пацифістська демонстрація», «Розвідка художніх копалин», «Таз» (присвята «Мухоморам»), «[Чендж]». Втім, глибший аналіз ролі авторського тексту в означених творах потребує додаткових даних.

5. Молоді одеські митці, чий дебют припав на 1980-ті роки (окрім Л. Войцехова, який дебютував у 1970-х) часто працювали 3 текстом у рамках власних художніх практик. Дослідження тексту в їхніх перформансах, отже, є перспективним. На жаль, матеріалів онлайн-архіву «Мистецтво Одеси 80-х» виявилося замало для проведення грунтовного аналізу ролі авторських текстів у перформансах. Проте, серед огрому мережевих ресурсів, даний є найбільш достовірним, оскільки містить унікальні спогади митців (окремі 3 них уже покійні). Також відзначимо невелику часову відстань, що розділяла упорядників архіву й перформанси, про які йде мова (один 3 інтерв’юерів, В. Беспрозванний, був також свідком подій). Тому дані онлайн-архіву 
«Мистецтво Одеси 80-х»є цінним джерелом для дослідження перформансів в Одесі означеного періоду.

\section{СПИСОК ВИКОРИСТАНИХ ДЖЕРЕЛ}

1. Беспрозванный В. Леонид Войцехов. Интервью [Електронний ресурс] // Мистецтво Одеси 80-х : архів. - 2000.- Режим доступу до ресурсу: http://kiev.guelman.ru/odessa/voicehov/interview.html.

2. Година Е. Игорь Чаџкин. Интервью [Електронний ресурс] // Мистецтво Одеси 80$\mathrm{x} \quad$ : архів. - 2000. - Режим доступу до ресурсу: http://kiev.guelman.ru/odessa/chatskin/interview.html.

3. Беспрозванный В. Юрий Лейдерман. Интервью [Електронний ресурс]// Мистецтво Одеси 80-х : архів. - 2000.- Режим доступу до ресурсу: http://kiev.guelman.ru/odessa/leiderman/interview.html.

4. Беспрозванный В. Перцьь. Интервью [Електронний ресурс] // Мистецтво Одеси 80-х : архів. - 2000. - Режим доступу до ресурсу: http://kiev.guelman.ru/odessa/percy/interview.html.

5. Беспрозванный В. Андрей Монастырский. Интервью при участии Юрия Лейдермана [Електронний ресурс]// Мистецтво Одеси 80-х : архів. - 2000. Режим доступу до ресурсу: http://kiev.guelman.ru/odessa/moscow/monastyrsky.html.

6. Година Е. Сергей Ануфриев. Интервью [Електронний ресурс] // Мистецтво Одеси 80-х : архів. - 2000.- Режим доступу до ресурсу: http://kiev.guelman.ru/odessa/anufriev/interview.html.

7. Лейдерман Ю. Рисунки к акции Ю. Лейдермана «Это тайное слово» 1982-83 [Електронний ресурс] // Мистецтво Одеси 80-х : архів. - 2000. - Режим доступу до pecypcy: http://kiev.guelman.ru/odessa/leiderman/pictures/tainoe.html.

8. Беспрозванный В. Александр Петрелли. Интервью [Електронний ресурс] // Мистецтво Одеси 80-х : архів. - 2000.- Режим доступу до ресурсу: http://kiev.guelman.ru/odessa/petrelli/interview.html.

9. Лейдерман Ю. Эскизы к перформансу Ю. Лейдермана и И. Чаџкина «Спобы убийства флагом» 1983 [Електронний ресурс] // Мистецтво Одеси 80-х : архів. 2000. - Режим доступу до ресурсу: http://kiev.guelman.ru/odessa/leiderman/pictures/sposoby.html.

10. Беспрозванный В. Мартынчики. Интервью [Електронний ресурс] // Мистецтво Одеси 80-х : архів. - 2000.- Режим доступу до ресурсу: http://kiev.guelman.ru/odessa/martyn/interview.html.

11. Беспрозванный В. Константин Звездочетов. Интервью [Електронний ресурс] // Мистецтво Одеси 80-х : архів. - 2000.- Режим доступу до ресурсу: http://kiev.guelman.ru/odessa/moscow/zvezdochetov.html.

12. Година Е. Игорь Каминник. Интервью [Електронний ресурс] // Мистецтво Одеси 80-х : архів. - 2000.- Режим доступу до ресурсу: http://kiev.guelman.ru/odessa/fomsky/kaminnik.html.

13. Година Е. Стас Подлипский. Интервью [Електронний ресурс] // Мистецтво Одеси 80-х : архів. - 2000. - Режим доступу до ресурсу: http://kiev.guelman.ru/odessa/podlipsky/interview.html.

14. Лист Ігоря Чацкіна до Юрія Лейдермана. Грудень 1981 р. [Електронний ресурс] // Мистецтво Одеси 80-х : архів.- Режим доступу до ресурсу: http://kiev.guelman.ru/odessa/chatskin/texts.html.

15. Година Е. Дмитрий Нужин. Интервью [Електронний ресурс] // Мистецтво Одеси 80-х : архів. - 2000. - Режим доступу до ресурсу: http://kiev.guelman.ru/odessa/nuzhin/interview.html. 


\section{REFERENCES}

1. Besprozvannyiy V. Leonid Vojcehov. Interview in Odessa Art in 80s Archive, 2000. Retrieved from http://kiev.guelman.ru/odessa/voicehov/interview.html.

2. Godina E. Igor' Čackin. Interview in Odessa Art in 80s Archive, 2000. Retrieved from http://kiev.guelman.ru/odessa/chatskin/interview.html.

3. Besprozvannyiy V. Jurij Lejderman. Interview in Odessa Art in 80s Archive, 2000. Retrieved from http://kiev.guelman.ru/odessa/leiderman/interview.html.

4. Besprozvannyiy V. Percy. Interview in Odessa Art in 80s Archive, 2000. Retrieved from http://kiev.guelman.ru/odessa/percy/interview.html.

5. Besprozvannyiy V. Andrey Monastyrskij. Interview where Jurij Lejderman also participated in Odessa Art in 80s Archive, 2000. Retrieved from http://kiev.guelman.ru/odessa/moscow/monastyrsky.html.

6. Godina E. Sergej Anufriev. Interview in Odessa Art in 80s Archive, 2000. Retrieved from http://kiev.guelman.ru/odessa/anufriev/interview.html.

7. Lejderman J. The drawings for Jurii Leiderman's performance 'This Secret Word' 1982-83 in Odessa Art in 80s Archive, 2000. Retrieved from http://kiev.guelman.ru/odessa/leiderman/pictures/tainoe.html.

8. Besprozvannyiy V. Alexandr Petrelli. Interview in Odessa Art in 80s Archive, 2000. Retrieved from http://kiev.guelman.ru/odessa/petrelli/interview.html.

9. Lejderman J. Sketches for Jurii Leiderman's and Igor' Čackin's performance 'Flag Killing Methods' 1983 in Odessa Art in 80s Archive, 2000. Retrieved from http://kiev.guelman.ru/odessa/leiderman/pictures/sposoby.html.

10. Besprozvannyiy V. Martynčiki. Interview in Odessa Art in 80s Archive, 2000. Retrieved from http://kiev.guelman.ru/odessa/martyn/interview.html.

11. Besprozvannyiy V. Konstantin Zvezdočetov. Interview in Odessa Art in 80s Archive, 2000. Retrieved from http://kiev.guelman.ru/odessa/moscow/zvezdochetov.html.

12. Godina E. Igor' Kaminnik. Interview in Odessa Art in 80s Archive, 2000. Retrieved from http://kiev.guelman.ru/odessa/fomsky/kaminnik.html.

13. Godina E. Stas Podlipskij. Interview in Odessa Art in 80s Archive, 2000. Retrieved from http://kiev.guelman.ru/odessa/podlipsky/interview.html.

14. Letter from Igor' Čackin to Jurii Leiderman. December 1981 in Odessa Art in 80s Archive, 2000. Retrieved from http://kiev.guelman.ru/odessa/chatskin/texts.html.

15. Godina E. Dmitrij Nužyn. Interview in Odessa Art in 80s Archive, 2000. Retrieved from http://kiev.guelman.ru/odessa/nuzhin/interview.html.

Надійшла до редакиії 17 лютого 2020 р.

\section{ІЛЮСТРАЦІї ДО СТАТТІ}

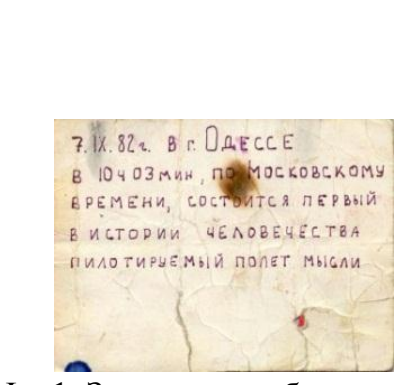

Іл. 1. Записка-атрибут.

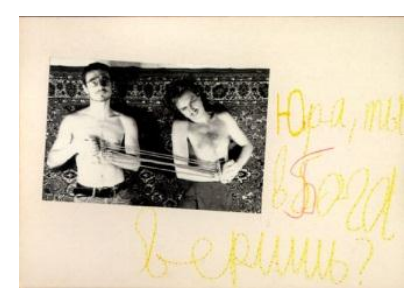

Іл. 2. Сторінка з альбому С.Ануфрієва «Мадонни» (1980-ті).

3 колекції А. Монастирського. На світлині Ю. Лейдерман, I. Чацкін.

Напис: «Юра, ти в Бога віриш?»

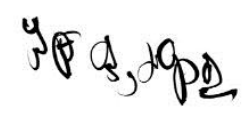

Іл. 3.

Рисунок-атрибут. Напис:«Ура, Юра» 


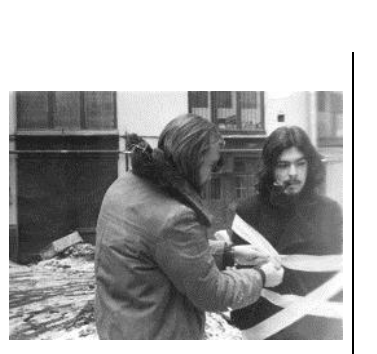

ФОТОГРАФІї ДО СТАТТІ

Фото 1. «ХрестикНулик». С. Ануфрієв, В. Наумець.

3 приватного архіву М. Жаркової.

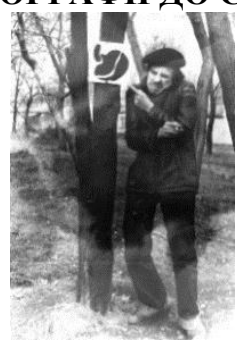

Фото 2. «Російська ідилія» (1982).

На фото І. Чацкін.

3 приватного архіву

Ю. Лейдермана.

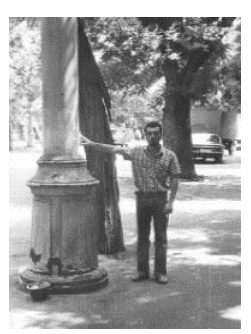

Фото 3. «Притулившись до стовпа» (1983). На фото: Ю. Лейдерман.

Світлина 3 приватного архіву Ю. Лейдермана
Фото 4. «Між іншим» (1983).

На фото: Л. Войцехов.

3 приватного архіву

Л. Войцехова.

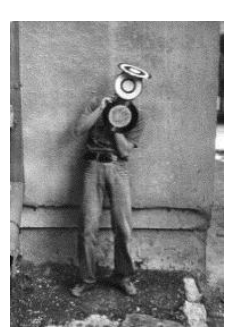

Фото 5. «Щит Давида» (1983).

Фото 3 приватного архіву Ю. Лейдермана.

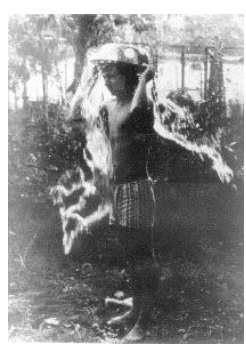

Фото 7. «Таз», присвята «Мухоморам» (1984). На фото О. Петреллі.

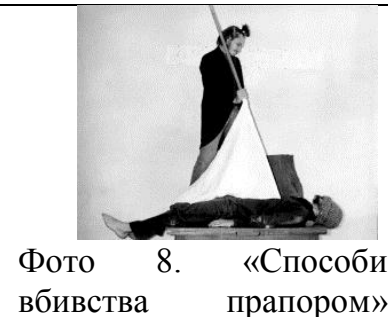

(1985).

На фото: Ю. Лейдерман (лежить), I. Чацкін (стоїть).

3 приватного архіву Л. Войцехова.

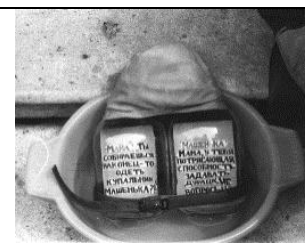

Фото 10. Об'єкт-атрибут перформансу «Розвідка художніх копалин» (1987).

3 приватного Ю. Лейдермана apxiвy

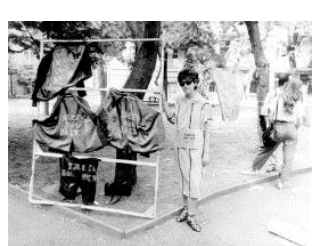

Фото 11. «Тут був Вася» (1987).

На фото: С. Мартинчик. 3 приватного архіву «Мартинчиків».

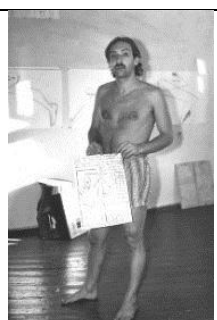

Фото 6. «Це таємне слово» (1984).

На фото Л. Войцехов.

3 приватного архіву Ю. Лейдермана.

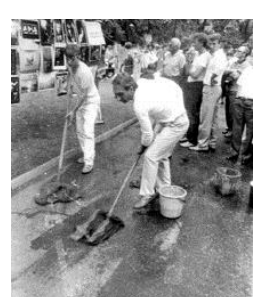

Фото 9. «В два рахунки» (1987).

На фото: Л. Войцехов.

3 приватного архіву Л. Войцехова.

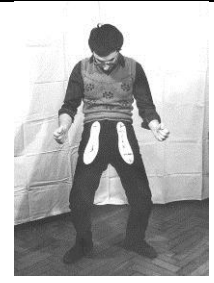

Фото 12. «Устілки» (1983 1984).

На фото Ю. Лейдерман.

3 приватного архіву Ю. Лейдермана. 
«Філологічні трактати», Том 12, № 1' 2020 